medRxiv preprint doi: https://doi.org/10.1101/2022.02.21.22271299; this version posted February 22, 2022. The copyright holder for this preprint (which was not certified by peer review) is the author/funder, who has granted medRxiv a license to display the preprint in It is made available under a CC-BY-NC-ND 4.0 International license.

\title{
Psychological and financial impacts of COVID-19-related travel measures: An international cross-sectional study
}

\author{
Authors: Pippa McDermid ${ }^{1}$, Soumya Sooppiyaragath ${ }^{2}$, Adam Craig ${ }^{1}$, Meru Sheel $^{3}$, \\ Katrina Blazek ${ }^{1}$, Siobhan Talty ${ }^{4}$, and Holly Seale ${ }^{1}$
}

\section{Authors Affiliations}

1. School of Population Health, University of New South Wales, Sydney, NSW, Australia.

2. Independent Research Psychologist. Bsc Psych, Msc App Clinical Psych. MAPPI.

3. Sydney School of Public Health, Faculty of Health and Medicine, the University of Sydney, Sydney, NSW, Australia.

4. Freelance Monitoring, Evaluation, Accountability and Learning Technical Advisor, ME(AL). TA.

\section{Correspondence}

Associate Professor. Holly Seale

School of Population Health

Level 2, Samuels Building

Faculty of Medicine, UNSW Australia

Sydney 2052, Australia

Telephone: +61 (2) 93853129

Email: h.seale@unsw.edu.au

Word count:

Abstract: 324; Main body: 2994

Keywords: COVID-19; Pandemic; Public Health; Travel; Depression; Anxiety; Stress; Movement 
medRxiv preprint doi: https://doi.org/10.1101/2022.02.21.22271299; this version posted February 22, 2022. The copyright holder for this preprint (which was not certified by peer review) is the author/funder, who has granted medRxiv a license to display the preprint in

It is made available under a CC-BY-NC-ND 4.0 International license .

\section{ABSTRACT}

Background: The impact of COVID-19 international travel restrictions has to date, not been fully explored, and with the ongoing threat that new variants could potentially restrict movement further, it is important to consider the impacts that travel restrictions have on community members. This study aimed to evaluate the psychological and financial impact of COVID-19 travel restrictions on those separated from their partners or immediate families, as well as temporary visa holders who were unable to migrate.

Methods: Between 4 November 2021 to 1 December 2021, we executed a cross-sectional online survey targeting three specific groups; (1) those stranded from their partners; (2) those stranded from immediate families; and (3) temporary visa holders unable to migrate or cross international borders. We collected data on respondents' demographic profile; the nature of COVID-19-related travel impacts; depression, anxiety, and stress levels (using the validated DASS-21); and finally, data on respondents financial, employment and accommodation situation.

Results: 1363 respondents located globally completed the survey. $71.2 \%$ reported financial stress, $76.8 \%(\overline{\mathrm{x}}=11.57, \mathrm{SD}=5.94)$ reported moderate-to-extremely severe depression, $51.6 \%$ $(\overline{\mathrm{x}}=6.80, \mathrm{SD}=5.49)$ moderate-to-extremely severe anxiety, and $62.6 \%(\overline{\mathrm{x}}=11.52, \mathrm{SD}=5.55)$ moderate-to-extremely severe stress levels. Statistically significant factors associated with moderate-to-extremely severe depression, anxiety, and stress included being female, chronic illness, and experiencing financial stress. Employment during COVID-19 - specifically essential services workers or unemployed - was associated with higher levels of anxiety and stress, with only essential workers being a predictor of higher stress severity. Factors that provided psychological protection included being older and having children.

Conclusion: This study is one of the first to explore the impact COVID-19-related international travel restrictions have had on the financial status and psychological health of affected individuals. It highlights the significant human cost associated with the restrictions and identifies psychologically vulnerable populations. These results will help the design of targeted health and social policy responses. 
medRxiv preprint doi: https://doi.org/10.1101/2022.02.21.22271299; this version posted February 22, 2022. The copyright holder for this preprint (which was not certified by peer review) is the author/funder, who has granted medRxiv a license to display the preprint in It is made available under a CC-BY-NC-ND 4.0 International license .

\section{BACKGROUND}

International mobility has changed dramatically in the wake of the COVID-19 pandemic. The rapid introduction of international travel restrictions in early 2020 resulted in a huge downward shift in cross-border movements of individuals globally with many people finding themselves stranded abroad (1-4). At the end of the second year of the pandemic (December 2021), some countries continued to maintain strict international border controls, with frequent changes to travel and border-control policies. In response to the omicron variant, a proportion of countries had reinstated a ban on travellers from high-risk countries, others continued to impose total border closure, or stringent quarantine/screening requirements on international arrivals (5). Furthermore, with new COVID-19 variants expected, the level of uncertainty about international travel restrictions continues and border controls will likely remain a frequently used emergency response (6).

Major economic concerns have been raised globally about the impact of travel restrictions, specifically those denying entry to tourists, skilled workers and international students, due to the impacts this will have on country income, productivity, labour supply, university funding and growth (7-9). Beyond the negative economic effects of denying entry to these groups, are the potential psychological and financial impacts on the individual (10). Research thus far has explored the impact of COVID-19 on short-term migrant workers within the country that they are working, and found that this group is one of the most vulnerable to unemployment, depression, food insecurity and homelessness $(11,12)$.

In addition to the skilled workers and visa holders who have been unable to enter certain countries, travel restrictions have resulted in the forced separated of families and partners during the pandemic, increasing the risk of social isolation. Stories emerged in both the social and mass media channels, of children being separated from their parents (13), as well as family members being unable to travel to visit sick and elderly family members (14). 
medRxiv preprint doi: https://doi.org/10.1101/2022.02.21.22271299; this version posted February 22, 2022. The copyright holder for this preprint (which was not certified by peer review) is the author/funder, who has granted medRxiv a license to display the preprint in It is made available under a CC-BY-NC-ND 4.0 International license .

Current evidence has focused on the impacts of lockdowns and social distancing measures on romantic relationships, with findings reflecting increasing rates of loneliness, social isolation and negative impacts on the general health and well-being of populations globally (15).

Previously our team examined the psychological and financial distress reported by citizens and permanent residents stranded abroad due to international travel restrictions introduced in response to the COVID-19 pandemic. This study was open to any individual stranded abroad from their country of citizenship or permanent residence due to international travel restrictions and was conducted between June to September 2021. We found that the psychological and financial impact for citizens and permanent residents stranded abroad due to international travel restrictions was great, with participants reporting moderate to severe levels of anxiety and stress (16). However, voluntary feedback received from respondents, coupled with commentary on social media, highlighted that our previous study failed to fully capture the impact and issues relevant to travellers separated from their partners or immediate families, and those unable to enter or return to the country where they hold a temporary visa during the COVID-19 pandemic (henceforth "temporary visa holders". Therefore, building on from that initial study, this subsequent work aimed to evaluate the psychological and financial impacts of those traveller groups.

\section{METHODS}

\section{Study population and procedures}

An international cross-sectional survey was designed to evaluate the psychological and financial impact of COVID-19-related travel restrictions. The online survey was developed using survey tool Qualtrics (17) and respondents recruited through a variety of Twitter and Facebook group posts. In addition to this, we emailed information about the study and a link to the survey to a previously collected list of impacted individuals who, as part of an effort to count the number of people affected by Australian border closures run by a grassroots 
medRxiv preprint doi: https://doi.org/10.1101/2022.02.21.22271299; this version posted February 22, 2022. The copyright holder for this preprint (which was not certified by peer review) is the author/funder, who has granted medRxiv a license to display the preprint in It is made available under a CC-BY-NC-ND 4.0 International license .

advocacy group, opted in to be contacted about future research opportunities regarding separated families and partners and stranded travellers. The online Qualtrics survey took on average 12.25 minutes to complete. Data was collected from 4 November 2021 to 1 December 2021.

Participants were eligible if, due to COVID-19-related travel restrictions, they had experienced separation from an immediate family member or partner OR were a temporary resident unable to enter or return to their country of temporary residence country. A unique IP address was applied to each survey response to prevent duplicate entries. Respondents' anonymity was maintained.

Ethical approval for this study was granted by the UNSW Human Research Ethics Committee (\#210418). All respondents indicated their consent to participate.

\section{Survey instruments and measures}

The survey collected data about: sociodemographic characteristics; types and perceived degree of impact of the COVID-19-related travel restrictions; the impact the experience had on their mental wellbeing and their access to psychological support; and the financial impacts of their experience. The self-reporting, 21-item Depression, Anxiety, and Stress Scale (DASS-21) (18) was used to measure three aspects of psychological distress and was selected due to its frequent use in studies of mental health during COVID-19 (19-21). It contains 21 questions assessing the level of symptom severity using a 4-point Likert scale from 0 to 3 (0: 'did not apply to me at all', 1: 'applied to me some of the time', 2: 'applied to me a good part of the time', and 3: 'applied to me most of the time'. Scores in each section are multiplied by 2 to calculate the final score. Using a key, the resulting scores are categorised as normal, mild, moderate, severe, or extremely severe depression, anxiety, or stress (DAS). Due to the timeframe of recall while completing the DASS-21 being longer than 2-weeks for some participants, an additional 'do not recall' option was added. Any participants scores who 
medRxiv preprint doi: https://doi.org/10.1101/2022.02.21.22271299; this version posted February 22, 2022. The copyright holder for this preprint (which was not certified by peer review) is the author/funder, who has granted medRxiv a license to display the preprint in It is made available under a CC-BY-NC-ND 4.0 International license .

selected 'do not recall' was to be omitted from analysis to maintain validity. Questions within the survey were open and closed ended, with a range of binary questions ('yes/no'), ordinal and nominal scale and Likert scale questions.

\section{Statistical analysis}

Descriptive analysis involved the calculation of means, standard deviations, confidence intervals and standard errors for continuous variable data, and the calculation of counts and proportions for categorical variables data. To test significance, we used one-way ANOVA analyses (for continuous variables) and Chi-square analyses or a Fishers exact test for smaller cell sizes (for categorical variables). Any variables found to show a significant association with DASS severity $(\mathrm{p}<.2)$ was chosen to be included in the model as predictor variables. We dichotomised DASS scores to indicate either no-mild symptom severity or moderate-toextremely severe symptom severity. Finally, we conducted multivariable binary logistic regression to determine demographic, financial, and occupational predictors of moderate to extremely severe depression, anxiety, and stress. All analyses were conducted with SPSS (22). No errors, influential outliers or multicollinearity amongst variables was identified. Statistical significance was $\mathrm{p}>0.05$.

\section{RESULTS}

\section{Participant Characteristics}

A total of 1363 respondents completed the survey. Table 1 summarises their sociodemographic characteristics. The mean $\pm \mathrm{SD}$ age of respondents was $36.7 \pm 11.21$ years, ranging from 18 to 85 years, with most being female $(73.5 \%, 1002 / 1363)$, having a tertiary education $(91.9 \%, 1253 / 1363)$ and separated from their immediate family $(50.6 \%, 690 / 1363)$.

Table 1. Sociodemographic characteristics of temporary visa holders unable to immigrate and those separated from their partner or immediate family during COVID-19 
medRxiv preprint doi: https://doi.org/10.1101/2022.02.21.22271299; this version posted February 22, 2022. The copyright holder for this preprint (which was not certified by peer review) is the author/funder, who has granted medRxiv a license to display the preprint in It is made available under a CC-BY-NC-ND 4.0 International license.

Eligibility

Separated from immediate

(1363)

family

Separated from partner/spouse

Temporary visa holders unable

690

50.6

to emigrate

\begin{tabular}{|c|c|c|c|}
\hline Gender & & $(\mathbf{1 3 6 3 )}$ & \\
\hline & Woman/Female & 1002 & 73.5 \\
\hline & Man/Male & 348 & 25.5 \\
\hline & Prefer not to say & 10 & .7 \\
\hline & Another term & 3 & .2 \\
\hline Main language spoken at home & & $(\mathbf{1 3 6 3 )}$ & \\
\hline & English & 959 & 70.4 \\
\hline & Other & 339 & 24.9 \\
\hline & Spanish & 36 & 2.6 \\
\hline & French & 18 & 1.3 \\
\hline & Chinese & 9 & .7 \\
\hline & Russian & 2 & .1 \\
\hline Highest level of education & & $(\mathbf{1 3 6 3 )}$ & \\
\hline & Tertiary education & 1253 & 91.9 \\
\hline & Secondary education & 101 & 7.4 \\
\hline & Primary education & 6 & .4 \\
\hline & No formal education & 3 & .2 \\
\hline Employment during COVID-19 & & $(1363)$ & \\
\hline & Other & 626 & 45.9 \\
\hline & Not in paid work & 193 & 45.9 \\
\hline & Essential services worker & 177 & 13 \\
\hline & Health worker & 135 & 9.9 \\
\hline & Educator & 134 & 9.8 \\
\hline & Government worker & 67 & 4.9 \\
\hline & Retired & 31 & 2.3 \\
\hline Children & & $(1363)$ & \\
\hline & Yes & 823 & 60.4 \\
\hline & No & 540 & 39.6 \\
\hline Children under 18 & & $(468)$ & \\
\hline & 0 & 30 & 6.4 \\
\hline & 1 & 214 & 51.5 \\
\hline & 2 & 145 & 31 \\
\hline & 3 & 40 & 8.5 \\
\hline & 4 or more & 12 & 2.5 \\
\hline Chronic illness & & $(\mathbf{1 3 6 3 )}$ & \\
\hline & Yes & 147 & 10.8 \\
\hline & No & 1174 & 86.1 \\
\hline & Unsure & 42 & 3.1 \\
\hline
\end{tabular}

AFR, African Region; AMR, Region of the Americas; SEAR, South-East Asian Region; EUR, European Region; EMR, Eastern Mediterranean Region; WPR, Western Pacific Region

\section{Travel experiences}

The mean \pm SD length of the time stranded, ranged from 1 to 23 months. For participants separated from partners it was $17.3 \pm 5.3$ months $(n=427), 20.7 \pm 3.6$ months $(n=690)$ for those 
medRxiv preprint doi: https://doi.org/10.1101/2022.02.21.22271299; this version posted February 22, 2022. The copyright holder for this preprint (which was not certified by peer review) is the author/funder, who has granted medRxiv a license to display the preprint in It is made available under a CC-BY-NC-ND 4.0 International license .

separated from immediate family and $17.1 \pm 5.2$ months $(\mathrm{n}=246)$ for temporary visa holders.

Table 2 summarises the main travel experiences of respondents separated by situation, with those respondents separated from their partners mostly reporting difficulty obtaining entry exemptions $(56 \%, 239 / 427)$, entry restrictions without applicable exemptions $(51.6 \%$, $220 / 427)$ and expensive or unaffordable flights $(42.9 \%, 183 / 427)$ as the main concerns. For participants separated from their immediate family, most frequently reported experiences included expensive or unaffordable costs of quarantine $(66.4 \%, 458 / 690)$, expensive or unaffordable flights $(64.5 \%, 445 / 690)$ and a lack of flight availability $(63.8 \%, 440 / 690)$. Finally, for temporary visa holders the most frequently reported experience was entry restrictions with applicable exemptions but difficulty obtaining exemptions $(64.2 \%$, $158 / 246)$, entry restrictions without applicable exemptions $(58.9 \%, 145 / 246)$ and a lack of flight availability $(32.1 \%, 78 / 246)$.

\section{Table 2. Travel experiences of temporary visa holders unable to immigrate and those separated from their partner or immediate family during COVID-19}

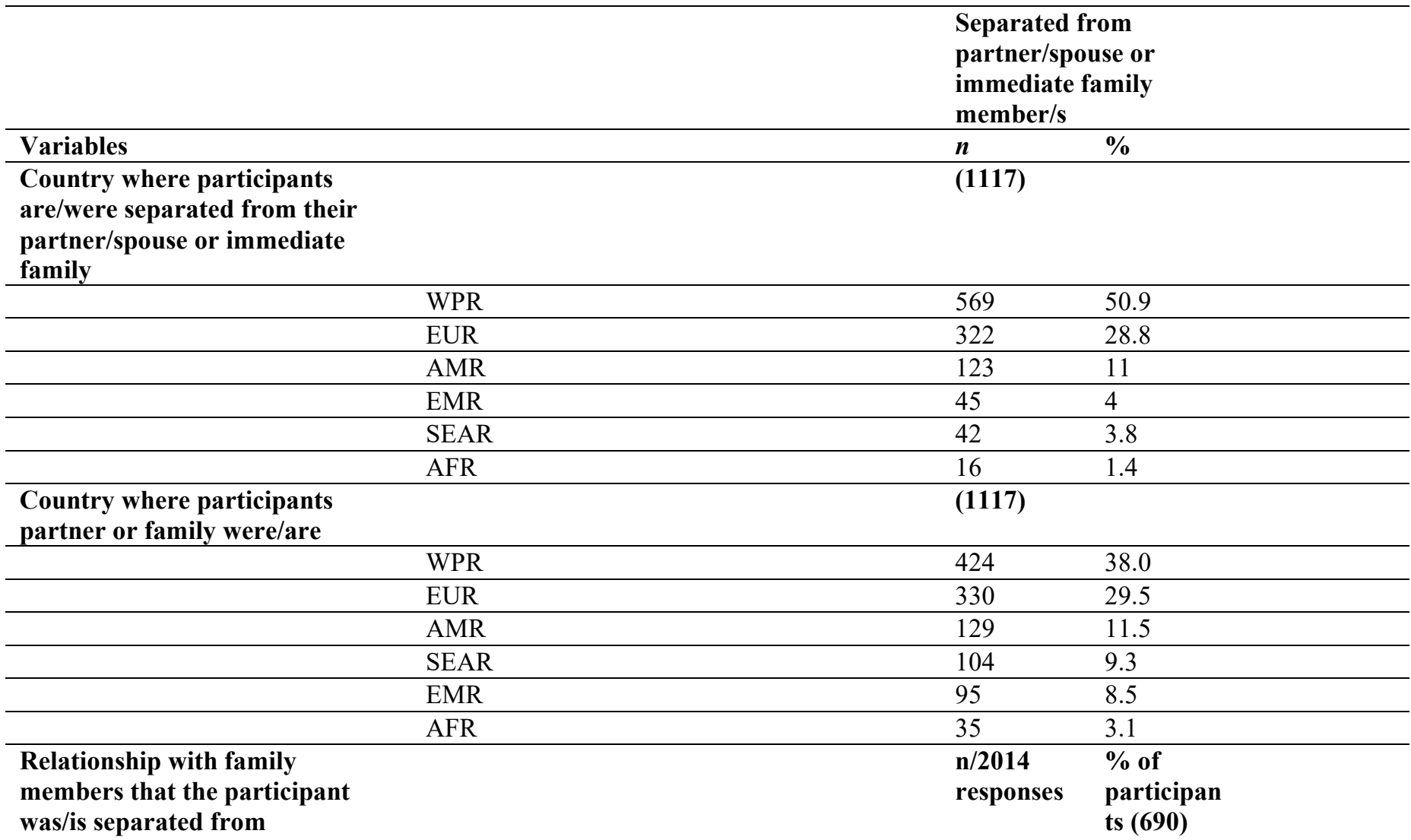


medRxiv preprint doi: https://doi.org/10.1101/2022.02.21.22271299; this version posted February 22, 2022. The copyright holder for this preprint (which was not certified by peer review) is the author/funder, who has granted medRxiv a license to display the preprint in

It is made available under a CC-BY-NC-ND 4.0 International license .

Country where participants

Parents

$604 \quad 87.5$

Aunts/Uncles

448

87.5

Siblings

438

Grandparents

197

63.5

Children over 18

4.6

Other

90

Grandchildren

41

Stepparents

Children under 18

Spouse

Stepchildren

$40 \quad 5.8$

$32 \quad 4.6$

$21 \quad 3$

$7 \quad 1$

are/were awaiting emigration

\begin{tabular}{llll}
\hline SEAR & 104 & 42.3 \\
\hline & EMR & 46 & 18.7 \\
\hline WPR & 35 & 14.2 & 11.8 \\
\hline EUR & 29 & 8.5 & \\
\hline AMR & 21 & 4.5 \\
\hline
\end{tabular}

\section{Country where participants hold \\ a temporary visa and are/were trying to enter or return}

(246)

\section{Initial reason for leaving the country where participants hold a temporary visa}

\begin{tabular}{lll} 
WPR & 216 & 87.8 \\
SEAR & 13 & 5.3 \\
\hline EUR & 7 & 2.8 \\
\hline EMR & 6 & 2.4 \\
AMR & 3 & 1.2 \\
\hline AFR & 3 & 1.2 \\
\hline
\end{tabular}

\section{(107)}

\begin{tabular}{lll} 
Visit family and/or friends overseas & 62 & 57.9 \\
\hline Other & 33 & 30.8 \\
Travel for business reasons & 4 & 3.7 \\
Holiday travel & 4 & 3.7 \\
Study & 3 & 2.8 \\
Travel to study overseas & 1 & .9
\end{tabular}

All participants

$\begin{array}{lll}\text { n(\%) of } & \mathbf{n}(\%) \text { of } & \mathbf{n}(\%) \text { of } \\ \text { Separated } & \begin{array}{l}\text { Separated } \\ \text { families }\end{array} & \begin{array}{l}\text { Temporary } \\ \text { visa holders }\end{array} \\ \text { partners } & \begin{array}{l}\text { (427) } \\ (690)\end{array} & (246)\end{array}$

\section{Travel experiences}

Lack of flight availability

Expensive or unaffordable flights

Expensive or unaffordable cost of quarantine

Entry restrictions with applicable exemptions

at the destination country, but difficulty

obtaining the exemption due to processing

delays or rejections

Fear of or unwillingness to travel due to risk of $128(30.0) \quad 353(51.2) \quad 25(10.2)$

border closures, flight cancellations or other

external factors

Entry restrictions without applicable

exemptions in the destination country

Exit restrictions in the departure country
$178(41.7) \quad 440(63.8) \quad 78(32.1)$

$183(42.9) \quad 445(64.5) \quad 65(26.4)$

$168(39.3) \quad 458(66.4) \quad 59(24.0)$

$239(56.0) \quad 186(27.0) \quad 158(64.2)$

$220(51.6) \quad 179(25.8) \quad 145(58.9)$

$147(34.4) \quad 305(44.2) \quad 16(6.5)$ 
medRxiv preprint doi: https://doi.org/10.1101/2022.02.21.22271299; this version posted February 22, 2022. The copyright holder for this preprint (which was not certified by peer review) is the author/funder, who has granted medRxiv a license to display the preprint in

It is made available under a CC-BY-NC-ND 4.0 International license .

Lack of time available for travel due to the

$112(26.2) \quad 287(41.6)$

$11(4.5)$

added time needed for quarantine

Lack of visa due to closed embassy or other

$137(32.1) \quad 64(9.3)$

$26(10.6)$ processing delays

$\begin{array}{llll}\text { Lack of knowledge of how to travel in the } & 58(13.6) & 120(17.4) & 16(6.5)\end{array}$

current global environment

Fear of, or unwillingness to travel due to risk $\quad 39(9.1) \quad 106(15.4) \quad 13(5.3)$

of contracting COVID-19

$\begin{array}{llll}\text { Possible to enter the destination country via a } & 52(12.2) & 65(9.4) & 6(2.4)\end{array}$

third country but cannot because of financial

cost, time cots, added risk or ethical reasons

\section{Mental wellbeing}

Mean values and standard deviations for each of the DASS-21 subscales were $11.6 \pm 5.9$ for depression, $6.8 \pm 5.5$ for anxiety and $11.5 \pm 5.6$ for stress. Converted, this translates to $76.8 \%$ (1046/1363) meeting the DASS-21 criteria for moderate-to-extremely severe depression, $51.6 \%(703 / 1363)$ between moderate-to-extremely severe anxiety, and 62.6\% (853/1363) between moderate-to-extremely severe stress. Figure 1 shows the distribution of DASS-21 mean scores by respondents' situation. The overwhelming majority of respondents reported a lack of government services offered to them, including mental health services, medical advice, emergency housing, financial assistance and traveller registration being offered to them (see Table 3). Furthermore, 9.4\% of respondents reported experiencing homelessness (a point where respondents reported having no shelter in place) while separated or awaiting migration.

Fig 1. Distribution of DASS21 severity for participants impacted by COVID-19 related travel restrictions

Table 3. Government services available to participants during COVID19

\begin{tabular}{llll}
\hline Variables & & $\boldsymbol{n}$ & $\mathbf{\%}$ \\
\hline Mental health services available & & & \\
\hline & Yes & 266 & 19.5 \\
\hline Medical advice available & No & 1097 & 80.5 \\
\hline & & & \\
\hline
\end{tabular}


medRxiv preprint doi: https://doi.org/10.1101/2022.02.21.22271299; this version posted February 22, 2022. The copyright holder for this preprint (which was not certified by peer review) is the author/funder, who has granted medRxiv a license to display the preprint in It is made available under a CC-BY-NC-ND 4.0 International license.

\begin{tabular}{llll} 
& No & 1168 & 85.7 \\
\hline Emergency housing available & & & \\
\hline & Yes & 19 & 1.4 \\
\hline $\begin{array}{l}\text { Government financial } \\
\text { assistance available }\end{array}$ & No & 1344 & 98.6 \\
\hline & Yes & \\
\hline & No & 124 & 9.1 \\
\hline Traveler registration available & & 1239 & 90.9 \\
\hline & Yes & & \\
\hline & No & 231 & 16.9 \\
\hline & & 1132 & 83.1 \\
\hline
\end{tabular}

\section{Financial wellbeing}

Mean expenditure ranged from $\$ 0$ to $\$ 136,779$ USD for respondents. For those separated from a partner their average was USD\$6078 (SD:11627), an average of USD\$5915 (SD:13923) was found for those separated from immediate family, and an average of USD\$12,651 (SD: 16036) for temporary visa holders.

Financial stress was reported by 71.2\% (971/1363) respondents. Of those separated from a partner/spouse or immediate family member, $64.9 \%(725 / 1117)$ of the respondents' partners' or family members' experienced financial stress. A change in employment status was experienced by $51.4 \%$ (700/1363), whereby most experienced having to work remotely (33.3\%, 257/1363), followed by loss of employment $(25.5 \%, 197 / 1363)$. Table 4 has a full breakdown of the main financial and employment characteristics of respondents.

\footnotetext{
Table 4. Financial and employment characteristics of temporary visa holders unable to immigrate and those separated from their partner or immediate family during COVID-19
}

\begin{tabular}{llll}
\hline Variables & & $\boldsymbol{n}$ & $\mathbf{\%}$ \\
\hline $\begin{array}{l}\text { Additional costs } \\
\text { incurred due to delays } \\
\text { in emigration or being } \\
\text { separated from } \\
\text { partner/immediate } \\
\text { family }\end{array}$ & & $\begin{array}{l}\text { n/5138 total } \\
\text { responses }\end{array}$ & $\begin{array}{l}\text { \% of } \\
\text { participants } \\
(1363)\end{array}$ \\
\hline & Deposits or payments for future travel planned & \\
\hline & COVID-19 tests required for travel & 638 & 55.3 \\
\hline & Application for travel exemption certificates or other & 637 & 55.2 \\
\hline & COVID related travel procedures & 54.7 \\
\hline & Cancelled, delayed, changed, or missed flights & 606 & 52.5 \\
\hline & Visa applications & 555 & 48.1 \\
\hline & Immigration lawyers or advisors & 425 & 36.8
\end{tabular}


medRxiv preprint doi: https://doi.org/10.1101/2022.02.21.22271299; this version posted February 22, 2022. The copyright holder for this preprint (which was not certified by peer review) is the author/funder, who has granted medRxiv a license to display the preprint in

It is made available under a CC-BY-NC-ND 4.0 International license .

\begin{tabular}{|c|c|c|c|}
\hline & Migration agents & 410 & 35.5 \\
\hline & Notaries, apostille or other legalisation processes & 364 & 31.5 \\
\hline & Mandatory quarantine & 291 & 25.2 \\
\hline & Additional accommodation & 276 & 23.9 \\
\hline & Translators for travel-related procedures & 165 & 14.3 \\
\hline & Other & 140 & 12.1 \\
\hline \multirow[t]{16}{*}{$\begin{array}{l}\text { Methods of } \\
\text { addressing additional } \\
\text { financial costs }\end{array}$} & & $\begin{array}{l}\mathrm{n} / 1634 \text { total } \\
\text { responses }\end{array}$ & $\begin{array}{l}\% \text { of } \\
\text { participants } \\
(1363)\end{array}$ \\
\hline & Accessed savings & 777 & 74.7 \\
\hline & Other & 149 & 14.3 \\
\hline & Taken on additional paid employment & 172 & 16.5 \\
\hline & Sold assets (House, investments etc) & 170 & 16.3 \\
\hline & $\begin{array}{l}\text { Accessed 'superannuation' or early access to pension } \\
\text { funds }\end{array}$ & 115 & 11.1 \\
\hline & Borrowed from a bank & 108 & 10.4 \\
\hline & $\begin{array}{l}\text { Accessed financial support from the social security } \\
\text { services }\end{array}$ & 44 & 4.2 \\
\hline & $\begin{array}{l}\text { Applied for a government grant (that you don't have to } \\
\text { pay back) for return flights }\end{array}$ & 44 & 4.2 \\
\hline & Received financial support from your employer & 38 & 3.7 \\
\hline & $\begin{array}{l}\text { Applied for a government loan (that you must pay back) } \\
\text { for living costs }\end{array}$ & 21 & 2 \\
\hline & $\begin{array}{l}\text { Applied for a government grant (that you don't have to } \\
\text { pay back) for living costs }\end{array}$ & 18 & 1.7 \\
\hline & Accessed financial support from charity services & 6 & 0.6 \\
\hline & Received financial support from an insurance company & 6 & 0.6 \\
\hline & Received financial support from a travel agent & 4 & 0.4 \\
\hline & $\begin{array}{l}\text { Applied for a government loan (that you must pay back) } \\
\text { for return flights }\end{array}$ & 3 & .3 \\
\hline \multirow[t]{12}{*}{ Employment change } & & $\begin{array}{l}\mathrm{n} / 1170 \text { total } \\
\text { responses }\end{array}$ & $\begin{array}{l}\% \text { of } \\
\text { participants } \\
(1363)\end{array}$ \\
\hline & Work remotely & 257 & 33.3 \\
\hline & Lost job & 197 & 25.5 \\
\hline & Other & 121 & 15.7 \\
\hline & Reduction of hours & 121 & 15.7 \\
\hline & Resigned & 113 & 14.6 \\
\hline & Pay cut & 84 & 10.9 \\
\hline & Stood down, not working for pay, but not fired & 76 & 9.8 \\
\hline & Back in paid work & 59 & 7.6 \\
\hline & Increase in hours & 58 & 7.5 \\
\hline & Contract not renewed & 46 & 6 \\
\hline & Not working but still being paid (jobkeeper, furlough) & 38 & 4.9 \\
\hline
\end{tabular}

\section{Comparative analysis of depression, anxiety, and stress}

There were significant associations between respondents DASS categories and their current

situation (separated or temporary visa holder), gender, mental health services offered,

medical advice offered, government financial assistance offered, traveller registration offered 
medRxiv preprint doi: https://doi.org/10.1101/2022.02.21.22271299; this version posted February 22, 2022. The copyright holder for this preprint (which was not certified by peer review) is the author/funder, who has granted medRxiv a license to display the preprint in It is made available under a CC-BY-NC-ND 4.0 International license.

(significant for depression only), financial stress, homelessness, employment change, having children, chronic illness, expenditure (significant for anxiety and stress only), and respondents' employment during COVID-19. No significant associations were found between DASS severity categories and having emergency accommodation offered, time separated/awaiting immigration (see Supplementary file 1).

For depression, logistic regression identified being female, having mental health services offered, financial stress, and chronic illness as predictors of moderate-to-extremely severe depression. Overall, the model showed goodness of fit to the data $(\chi 2(20)=82.751, \mathrm{p}<.001)$, and correctly discriminated $76.4 \%$ of cases.

For anxiety, logistic regression identified being female, having medical advice offered, government financial assistance offered, financial stress, homelessness, chronic illness, and employment during COVID-19, specifically being an essential services worker, as predictors of moderate-to-extremely severe anxiety. Overall, the model showed goodness of fit to the data $(\chi 2(20)=182.342, p<.001)$, and correctly discriminated $65.9 \%$ of cases. Finally for stress, logistic regression identified being separated from a partner, increased expenditure, being female, financial stress, chronic illness, and employment during COVID-19, specifically being an essential services worker or not in paid work, as predictors of moderateto-extremely severe stress. Overall, the model showed goodness of fit to the data $\left(\chi^{2}(20)=\right.$ $166.186, \mathrm{p}<.001$ ), and correctly discriminated $67.2 \%$ of cases. Being older and having children was associated with decreased odds of moderate-to-extremely severe DAS. Table 5 presents the results of the multivariable logistic regression. 


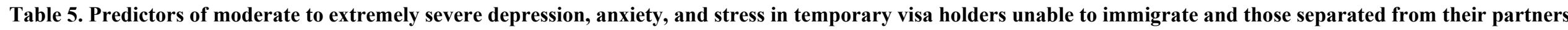
or immediate family members during COVID-19

\begin{tabular}{|c|c|c|c|c|c|c|c|c|c|c|c|c|}
\hline \multirow[b]{2}{*}{ Variables } & \multicolumn{4}{|c|}{ Depression } & \multicolumn{4}{|c|}{ Anxiety } & \multicolumn{4}{|c|}{ Stress } \\
\hline & OR & \multicolumn{2}{|c|}{$95 \% \mathrm{CI}$} & $p$ & OR & \multicolumn{2}{|c|}{$95 \% \mathrm{CI}$} & $p$ & OR & \multicolumn{2}{|c|}{$95 \% \mathrm{CI}$} & \multirow{2}{*}{.002} \\
\hline \multirow{2}{*}{\multicolumn{13}{|c|}{ Separated from partner/spouse* }} \\
\hline & & & & & & & & & & & & \\
\hline Separated from immediate family & .774 & .556 & 1.077 & .129 & .784 & .595 & 1.033 & .084 & .772 & .578 & 1.031 & .079 \\
\hline Temporary visa holders & .785 & .515 & 1.195 & .259 & .782 & .544 & 1.122 & .182 & .515 & .355 & .748 & $<.001$ \\
\hline Age & .983 & .969 & .998 & .023 & .969 & .957 & .983 & $<.001$ & .968 & .955 & .981 & $<.001$ \\
\hline Expenditure (actual amount/1000) & & & & & 1.037 & .974 & 1.103 & .255 & 1.104 & 1.028 & 1.186 & .007 \\
\hline \multicolumn{13}{|l|}{ Gender } \\
\hline \multicolumn{13}{|l|}{ Male* } \\
\hline Female & 1.469 & 1.065 & 2.026 & .019 & 1.691 & 1.265 & 2.260 & $<.001$ & 1.575 & 1.176 & 2.110 & .002 \\
\hline $\begin{array}{l}\text { Mental health services offered } \\
\text { (ref. no) }\end{array}$ & 1.592 & 1.026 & 2.471 & .038 & .934 & .656 & 1.330 & .706 & 1.357 & .936 & 1.968 & .108 \\
\hline $\begin{array}{l}\text { Medical advice offered } \\
\text { (ref. no) }\end{array}$ & 1.214 & .731 & 2.017 & .454 & 2.159 & 1.424 & 3.274 & $<.001$ & 1.444 & .935 & 2.232 & .098 \\
\hline $\begin{array}{l}\text { Government financial assistance } \\
\text { offered (ref. no) }\end{array}$ & 1.134 & .688 & 1.868 & .621 & 1.568 & 1.025 & 2.399 & .038 & 1.199 & .769 & 1.870 & .422 \\
\hline $\begin{array}{l}\text { Traveler registration offered } \\
\text { (ref. no) }\end{array}$ & .800 & .565 & 1.132 & .208 & & & & & & & & \\
\hline Financial Stress (ref. no) & 1.867 & 1.393 & 2.502 & $<.001$ & 2.246 & 1.713 & 2.946 & $<.001$ & 2.115 & 1.615 & 2.772 & $<.001$ \\
\hline Homelessness (ref. no) & 1.158 & .712 & 1.882 & .555 & 1.837 & 1.209 & 2.791 & .004 & 1.136 & .739 & 1.747 & .562 \\
\hline Employment change (ref. no) & .900 & .682 & 1.186 & .453 & .939 & .737 & 1.197 & .612 & 1.151 & .898 & 1.475 & .267 \\
\hline Children (ref. no) & .694 & .514 & .939 & .018 & .735 & .561 & .963 & .025 & .792 & .602 & 1.041 & .094 \\
\hline Chronic Illness (ref. no) & 1.707 & 1.054 & 2.765 & .030 & 1.662 & 1.133 & 2.437 & .009 & 2.111 & 1.384 & 3.220 & $<.001$ \\
\hline Employment during COVID-19 & & & & .188 & & & & .006 & & & & .042 \\
\hline Healthcare worker & .816 & .527 & 1.263 & .362 & .743 & .496 & 1.113 & .150 & .809 & .539 & 1.213 & .304 \\
\hline Government worker & 1.939 & .965 & 3.896 & .063 & 1.497 & .862 & 2.600 & .151 & 1.222 & .695 & 2.146 & .486 \\
\hline Essential services & 1.363 & .884 & 2.103 & .161 & 1.755 & 1.755 & 1.215 & .003 & 1.522 & 1.035 & 2.239 & .033 \\
\hline Educator & .973 & .615 & 1.538 & .906 & 1.023 & 1.023 & .681 & .914 & .970 & .640 & 1.471 & .887 \\
\hline Not in paid work & 1.219 & .804 & 1.849 & .350 & 1.296 & 1.296 & .906 & .156 & 1.533 & 1.054 & 2.229 & .026 \\
\hline Retired & 1.802 & .717 & 4.529 & .210 & 2.188 & 2.188 & .896 & .086 & 1.893 & .792 & 4.525 & .151 \\
\hline
\end{tabular}

Other *

\section{*Reference variable}

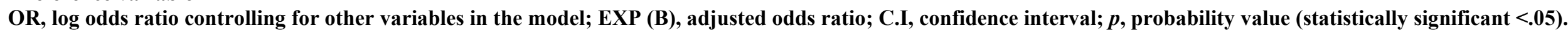

Notes. Only variables found to have been statistically significant $(<.2)$ from the chi-square analyses were included in each model. 
medRxiv preprint doi: https://doi.org/10.1101/2022.02.21.22271299; this version posted February 22, 2022. The copyright holder for this preprint (which was not certified by peer review) is the author/funder, who has granted medRxiv a license to display the preprint in It is made available under a CC-BY-NC-ND 4.0 International license .

\section{DISCUSSION}

In this study, we examined the prevalence and correlates of psychological and financial distress on those affected by COVID-19-related international travel restrictions and who, as a result, were unable to either, reunite with partners or immediate families, or enter/return to a country where they hold a temporary visa. In comparison to our initial study aimed at citizens and permanent residents stranded abroad in general (16), some differences have emerged between the groups of stranded travellers. The respondents in the current study reported higher values in depression and stress when compared to stranded citizens/permanent residents, who scored $64.2 \%, 64.4 \%$ and $41.7 \%$ respectively for depression, anxiety, and stress. Furthermore, when compared to DASS in the published COVID-19 studies and especially in studies focused on migrant workers (23-25), healthcare workers (20) or the general population $(19,21,26)$, the scores of the present study are dramatically higher, over $50 \%$ more severe in some cases. Along with research indicating that those negatively impacted by Australian international border closures were at an increased risk of elevated psychological distress (27), these scores combined provide additional evidence that travel restrictions have negative psychological consequences towards those directly impacted by them.

As direct social contact has been shown to be a protective factor for psychological distress (21), it may explain why our respondents had much higher scores compared to the other populations, as they were unable to be with friends or family, either directly because of travel restrictions or indirectly due to quarantine or lockdown. Research suggests that experiences that are distressing and demanding and which occur every day for longer than 6 months are considered a chronic psychological stressor which has been linked to early disease conditions and mortality (28). Given the impact of social isolation, loneliness and financial stress on mental health, and projected increase in suicide and suicide ideation reported in research 
medRxiv preprint doi: https://doi.org/10.1101/2022.02.21.22271299; this version posted February 22, 2022. The copyright holder for this preprint (which was not certified by peer review) is the author/funder, who has granted medRxiv a license to display the preprint in It is made available under a CC-BY-NC-ND 4.0 International license .

from Canada, USA, Pakistan, India, France and many others, these findings are particularly concerning (29-31). Results from this study can be used to assist in defining groups who are at an increased risk of developing moderate-to-extremely severe depression, anxiety, and stress due to international travel restrictions.

Our data suggests a significant financial burden on those impacted by travel restrictions, with respondents' average expenditure incurred $\$ 7,285$ USD and $71.2 \%$ reporting financial stress. These results are higher than those of our previous study (16) which reported financial stress in $64.2 \%$ and $45 \%$ experience an employment change. This difference could be due to the increased financial insecurity and visa issues/costs experienced by migrant workers, already evident in previous research $(11,12)$. Additionally, the respondents in this study reported unique additional costs of visa applications, travel certificates, cancelled or delayed flights, visa applications, migration agents and lawyers to name a few. Interestingly, we found that $64.9 \%$ of the respondents' partners' or family members' experienced financial stress due to the forced separation. This result warrants further research into the impacts of travel restrictions more broadly.

Of those that experienced a change in employment, $25.5 \%$ reported losing their job while separated from loved ones or awaiting immigration. This result is consistent with previous research during COVID-19 (32-34), with a study in South Africa reporting job loss rates of $30 \%$ (34) and a study on mothers and children experiencing adversity in Australia reporting $27 \%$ job and income loss (32). Previous literature suggests that experiences of employment changes and high additional expenditure can increase feelings of financial distress which in turn is likely to exacerbate psychological distress (34-36). Our findings reflect this with results showing financial distress caused by travel restrictions to be a statistically significant predictor of moderate-to-extremely severe DAS. 
medRxiv preprint doi: https://doi.org/10.1101/2022.02.21.22271299; this version posted February 22, 2022. The copyright holder for this preprint (which was not certified by peer review) is the author/funder, who has granted medRxiv a license to display the preprint in It is made available under a CC-BY-NC-ND 4.0 International license .

Our findings regarding respondents' experiences and perceptions towards the degree of government support reflects a very bleak picture, with almost all reporting that there was no support available, including no available mental health service $(80.5 \%)$, no medical advice available (85.7\%), no emergency housing available (98.6\%), no government financial assistance available (90.9\%) and finally no traveller registration available (83.1\%). These results, along with the varied support and services available to citizens stranded abroad evident in our previous study, especially that of mental health and emergency housing (37), reflect the ongoing inequity in access and availability of healthcare, resources, and services (38). Due to a perceived lack of government support along with high reported incidence of DASS severity and financial stress, we strongly recommend policymakers consider and mitigate the negative impacts of restricting temporary visa holders or immediate family members and partners from entering countries for reunification or migration purposes. Furthermore, we recommend policymakers introduce additional proactive support to those impacted by travel restrictions, specifically increasing the access and availability of community services, social support through mental health interventions and government financial aid, especially for immigration and visa support.

In line with results from our previous study and that of other research during COVID-19, women and those with chronic illness were found to be significantly associated with higher severity of DAS $(21,39,40)$. These results are consistent with evidence showing women and those with chronic illness to be more vulnerable to psychological problems than males and those without chronic illness $(21,41)$. Current evidence indicates both groups had increased fatality rates and disproportional effects during COVID-19, which could further exacerbate psychological distress linked to separation from loved ones or awaiting migration or travel $(42,43)$. 
medRxiv preprint doi: https://doi.org/10.1101/2022.02.21.22271299; this version posted February 22, 2022. The copyright holder for this preprint (which was not certified by peer review) is the author/funder, who has granted medRxiv a license to display the preprint in

It is made available under a CC-BY-NC-ND 4.0 International license .

Finally, results indicate that a respondent's situation (i.e. whether they were separated from family, separated from partner/spouse or delayed migration or travel on a temporary visa), was not the significant predictor of moderate to extremely severe depression or anxiety. This result suggests that for the most part, the negative psychological impacts of international travel restrictions did not vary depending on participant situation, and therefore evidence from this study provides a holistic picture of the psychological impacts felt by the many individuals impacted by travel restriction. However, it is also important to note, that we did not set the sample size up to compare between groups and so we may not have been sufficiently powered.

\section{Limitations}

This study has several limitations. Firstly, the results are based on a cross-sectional survey design, and lacks longitudinal follow up. Most respondents were female (73.5\%), educated to a tertiary level (91.9\%), with an ability to read English and exhibit a competent level of computer literacy due to the online survey format, which could bias results as it may not be fully representative of those impacted by international travel restrictions globally. Secondly, while we used a validated tool, our psychometric results were based on self-reporting, and as such could raise some subjectivity and bias issues as the scores reflect psychological distress not diagnosed by mental health professionals. Further, a baseline measure of mental health was not available or collected, and hence measurement in change due to COVID-19-related travel restrictions was not possible. Despite these limitations, the study provides novel insights into the wider impacts of travel restrictions beyond infection control.

\section{Conclusion}

Our findings suggest that international travel restrictions have significantly contributed to severe symptoms of depression, anxiety, and stress, as well as financial distress. Results indicate that for those impacted by COVID-19 related travel restrictions, being female, 
medRxiv preprint doi: https://doi.org/10.1101/2022.02.21.22271299; this version posted February 22, 2022. The copyright holder for this preprint (which was not certified by peer review) is the author/funder, who has granted medRxiv a license to display the preprint in

It is made available under a CC-BY-NC-ND 4.0 International license .

chronic illness and financial stress were predictors of moderate to extremely severe DAS.

Work status during COVID-19, specifically being an essential services worker or

unemployed were both predictors of higher anxiety, with only essential workers being a

predictor of higher stress severity. Being older and having children was associated with

decreased odds of moderate to extremely severe DAS. Most respondents reported no

government support being offered. The results of this study show both the psychological and

financial impacts of international travel restrictions, as well as a severe gap in government

services available that are vital to assisting vulnerable groups.

\section{ACKNOWLEDGMENTS}

\section{REFERENCES}

1. Chinazzi M, Davis JT, Ajelli M, Gioannini C, Litvinova M, Merler S, et al. The effect of travel restrictions on the spread of the 2019 novel coronavirus (COVID-19) outbreak.

Science. 2020;368(6489):395-400.

2. Seyfi S, Hall CM, Shabani B. COVID-19 and international travel restrictions: the geopolitics of health and tourism. Tourism Geographies. 2020:1-17.

3. von Tigerstrom BJ, Halabi SF, Wilson KR. The International Health Regulations (2005) and the re-establishment of international travel amidst the COVID-19 pandemic. Journal of Travel Medicine. 2020;27(8).

4. Munawar HS, Khan SI, Qadir Z, Kouzani AZ, Mahmud MAP. Insight into the Impact of COVID-19 on Australian Transportation Sector: An Economic and Community-Based Perspective. Sustainability. 2021;13(3):1276.

5. Hale T, Angrist N, Goldszmidt R, Kira B, Petherick A, Phillips T, et al. A global panel database of pandemic policies (Oxford COVID-19 Government Response Tracker). Nature Human Behaviour. 2021;5(4):529-38.

6. Karim SSA, Karim QA. Omicron SARS-CoV-2 variant: a new chapter in the COVID-19 pandemic. Lancet. 2021;398(10317):2126-8.

7. Jakobson M-L, Kalev L. COVID-19 Crisis and Labor Migration Policy: A Perspective From Estonia. Frontiers in Political Science. 2020;2. 
medRxiv preprint doi: https://doi.org/10.1101/2022.02.21.22271299; this version posted February 22, 2022. The copyright holder for this preprint (which was not certified by peer review) is the author/funder, who has granted medRxiv a license to display the preprint in It is made available under a CC-BY-NC-ND 4.0 International license .

8. de Lange T. COVID-19 Migration Policy Measures for International Students and Graduate Job Searchers: A Lost Round in the Battle for Brains. Frontiers in Human Dynamics. 2020;2.

9. Anderson B, Poeschel F, Ruhs M. Rethinking labour migration: Covid-19, essential work, and systemic resilience. Comparative Migration Studies. 2021;9(1):45.

10. Coates B, Sherel H, Mackay W. Rethinking permanent skilled migration after the pandemic. Grattan Institute; 2021.

11. Berg L, Farbenblum B. As If We Weren't Humans: The Abandonment of Temporary Migrants in Australia during COVID-19. Sydney: Migrant Worker Justice Initiative; 2020 2020/09/17.

12. Sommarribas A, Nienaber B. Migration and mobility of third-country national labour workers to and inside Europe during the Covid-19 pandemic - a legal analysis. Comparative Migration Studies. 2021;9(1):22.

13. Zhou N. 'It makes me sick': families of Australians stranded overseas devastated after arrivals cap slashed. The Guardian. 2021.

14. Trian N. Stranded abroad, Australians lodge UN petition against government for 'right to return home'. France 24. 2021.

15. Naser AY, Al-Hadithi HT, Dahmash EZ, Alwafi H, Alwan SS, Abdullah ZA. The effect of the 2019 coronavirus disease outbreak on social relationships: A cross-sectional study in Jordan. International Journal of Social Psychiatry.0(0):0020764020966631.

16. McDermid P, Craig A, Sheel M, Blazek K, Talty S, Seale H. Stranded abroad during the COVID-19 pandemic: examining the psychological and financial impact of border restrictions. medRxiv. 2021:2021.12.08.21267218.

17. Qualtrics. Qualtrics. Provo, Utah, USA2005.

18. Lovibond PF, Lovibond SH. Manual for the Depression Anxiety Stress Scales. Sydney: Psychology Foundation. 1995(2nd. Ed.).

19. Alkhamees AA, Alrashed SA, Alzunaydi AA, Almohimeed AS, Aljohani MS. The psychological impact of COVID-19 pandemic on the general population of Saudi Arabia. Comprehensive Psychiatry. 2020;102:152192.

20. Kabasakal E, Özpulat F, Akca A, Özcebe LH. Mental health status of health sector and community services employees during the COVID-19 pandemic. International Archives of Occupational and Environmental Health. 2021;94(6):1249-62. 
medRxiv preprint doi: https://doi.org/10.1101/2022.02.21.22271299; this version posted February 22, 2022. The copyright holder for this preprint (which was not certified by peer review) is the author/funder, who has granted medRxiv a license to display the preprint in It is made available under a CC-BY-NC-ND 4.0 International license.

21. Traunmüller C, Stefitz R, Gaisbachgrabner K, Schwerdtfeger A. Psychological correlates of COVID-19 pandemic in the Austrian population. BMC Public Health. 2020;20(1):1395.

22. IBM SPSS Statistics for Mac. 28 ed. Armonk, NY: IBM Corp.; 2021.

23. Saw YE, Tan EYQ, Buvanaswari P, Doshi K, Liu JCJ. Mental health of international migrant workers amidst large-scale dormitory outbreaks of COVID-19: A population survey in Singapore. Journal of Migration and Health. 2021;4:100062.

24. Hasan SI, Yee A, Rinaldi A, Azham AA, Mohd Hairi F, Amer Nordin AS. Prevalence of common mental health issues among migrant workers: A systematic review and metaanalysis. PLoS One. 2021;16(12):e0260221.

25. Harjana NPA, Januraga PP, Indrayathi PA, Gesesew HA, Ward PR. Prevalence of Depression, Anxiety, and Stress Among Repatriated Indonesian Migrant Workers During the COVID-19 Pandemic. Frontiers in Public Health. 2021;9.

26. Podubinski T, Glenister KM. The Pandemic Is Not Occurring in a Vacuum: The Impact of COVID-19 and Other Disasters on Workforce Mental Health in Australia. Disaster Med Public Health Prep. 2021:1-7.

27. Ali K, Iasiello M, van Agteren J, Mavrangelos T, Kyrios M, Fassnacht DB. A crosssectional investigation of the mental health and wellbeing among individuals who have been negatively impacted by the COVID-19 international border closure in Australia.

Globalization and Health. 2022;18(1):12.

28. Epel ES, Crosswell AD, Mayer SE, Prather AA, Slavich GM, Puterman E, et al. More than a feeling: A unified view of stress measurement for population science. Frontiers in Neuroendocrinology. 2018;49:146-69.

29. McIntyre RS, Lee Y. Preventing suicide in the context of the COVID-19 pandemic. World Psychiatry. 2020;19(2):250-1.

30. Mamun MA, Ullah I. COVID-19 suicides in Pakistan, dying off not COVID-19 fear but poverty? - The forthcoming economic challenges for a developing country. Brain Behav Immun. 2020;87:163-6.

31. Thakur V, Jain A. COVID 2019-suicides: A global psychological pandemic. Brain Behav Immun. 2020;88:952-3.

32. Bryson H, Mensah F, Price A, Gold L, Mudiyanselage SB, Kenny B, et al. Clinical, financial and social impacts of COVID-19 and their associations with mental health for mothers and children experiencing adversity in Australia. PLOS ONE. 2021;16(9):e0257357. 
medRxiv preprint doi: https://doi.org/10.1101/2022.02.21.22271299; this version posted February 22, 2022. The copyright holder for this preprint (which was not certified by peer review) is the author/funder, who has granted medRxiv a license to display the preprint in It is made available under a CC-BY-NC-ND 4.0 International license .

33. Singh K, Kondal D, Mohan S, Jaganathan S, Deepa M, Venkateshmurthy NS, et al. Health, psychosocial, and economic impacts of the COVID-19 pandemic on people with chronic conditions in India: a mixed methods study. BMC Public Health. 2021;21(1):685.

34. Posel D, Oyenubi A, Kollamparambil U. Job loss and mental health during the COVID-19 lockdown: Evidence from South Africa. PLOS ONE. 2021;16(3):e0249352.

35. McNamara CL, McKee M, Stuckler D. Precarious employment and health in the context of COVID-19: a rapid scoping umbrella review. European Journal of Public Health. 2021;31(Supplement_4):iv40-iv9.

36. Dawel A, Shou Y, Smithson M, Cherbuin N, Banfield M, Calear AL, et al. The Effect of COVID-19 on Mental Health and Wellbeing in a Representative Sample of Australian Adults. Frontiers in Psychiatry. 2020;11.

37. McDermid P, Craig A, Sheel M, Seale H. How have governments supported citizens stranded abroad due to COVID-19 travel restrictions? A comparative analysis of the financial and health support in eleven countries. BMC Infectious Diseases. 2022;22(1):161.

38. Perry BL, Aronson B, Pescosolido BA. Pandemic precarity: COVID-19 is exposing and exacerbating inequalities in the American heartland. Proc Natl Acad Sci U S A. $2021 ; 118(8)$.

39. Hou F, Bi F, Jiao R, Luo D, Song K. Gender differences of depression and anxiety among social media users during the COVID-19 outbreak in China:a cross-sectional study. BMC Public Health. 2020;20(1):1648.

40. Almalki AH, Alzahrani MS, Alshehri FS, Alharbi A, Alkhudaydi SF, Alshahrani RS, et al. The Psychological Impact of COVID-19 on Healthcare Workers in Saudi Arabia: A Year Later Into the Pandemic. Frontiers in Psychiatry. 2021;12.

41. Clarke DM, Currie KC. Depression, anxiety and their relationship with chronic diseases: a review of the epidemiology, risk and treatment evidence. Med J Aust. 2009;190(S7):S54-60.

42. Thibaut F, van Wijngaarden-Cremers PJM. Women's Mental Health in the Time of Covid-19 Pandemic. Frontiers in Global Women's Health. 2020;1.

43. Gimeno-Miguel A, Bliek-Bueno K, Poblador-Plou B, Carmona-Pírez J, Poncel-Falcó A, González-Rubio F, et al. Chronic diseases associated with increased likelihood of hospitalization and mortality in 68,913 COVID-19 confirmed cases in Spain: A populationbased cohort study. PLOS ONE. 2021;16(11):e0259822. 
medRxiv preprint doi: https://doi.org/10.1101/2022.02.21.22271299; this version posted February 22, 2022. The copyright holder for this preprint (which was not certified by peer review) is the author/funder, who has granted medRxiv a license to display the preprint in It is made available under a CC-BY-NC-ND 4.0 International license.

\section{SUPPORTING INFORMATION}

Supplementary file 1. Associations and variance between participant factors and levels of depression, anxiety, and stress $(\mathrm{n}=1363)$ 
Depression Severity

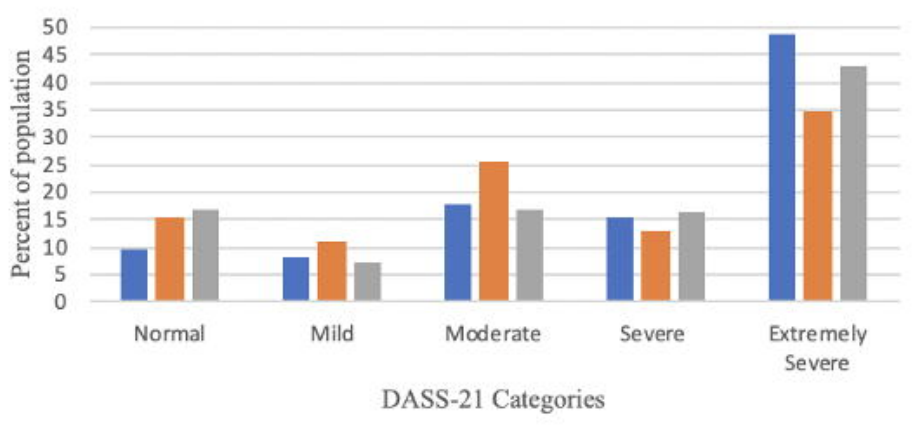

- Separated partners

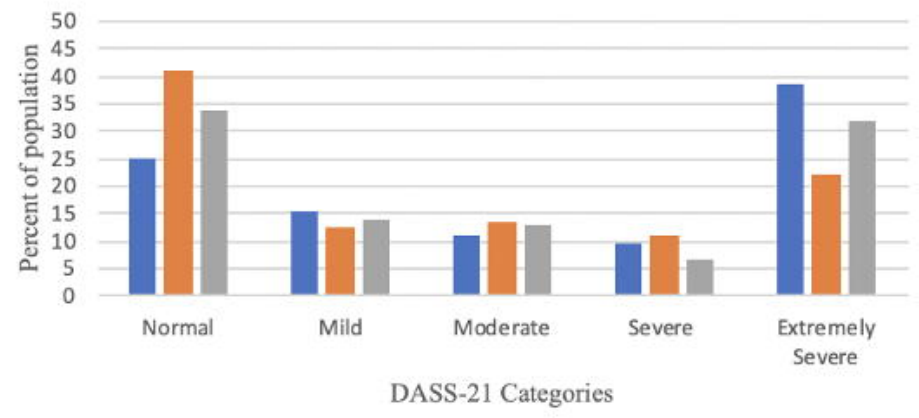

- Separated partners

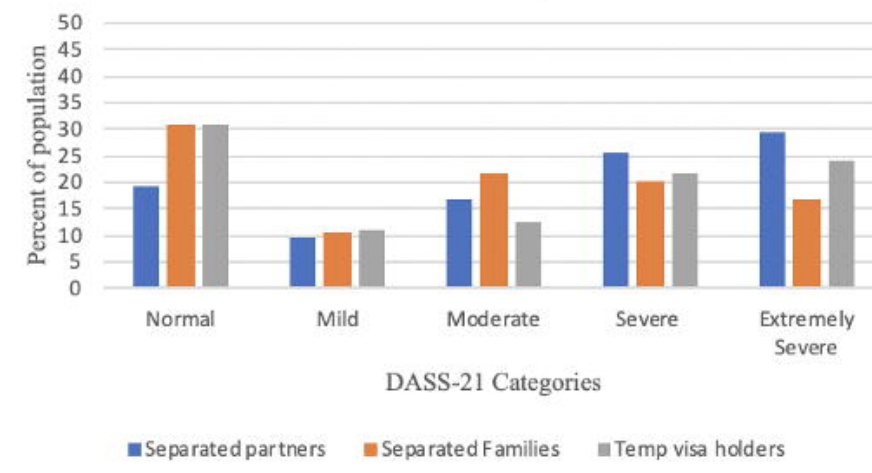

